\title{
Proteolytic Activities of a Rumen Bacterium, Bacteroides ruminicola $\mathrm{R8/4}$
}

\author{
By GEOFFREY P. HAZLEWOOD* AND ROBERT EDWARDS \\ Department of Biochemistry, A.R.C. Institute of Animal Physiology, Babraham, \\ Cambridge CB2 4AT, U.K.
}

(Received 1 December 1980; revised 8 January 1981)

\begin{abstract}
Proteolysis of leaf Fraction 1 protein, casein, azocasein and bovine serum albumin by the cell-associated proteinases of the rumen bacterium Bacteroides ruminicola R8/4 was investigated and the kinetic parameters $V_{\max }$ and $K_{\mathrm{m}}$ were evaluated for each substrate. A variety of proteinase inhibitors was used to show that the proteolytic activity comprises a mixture of at least three different classes of proteinase. With respect to substrate specificity and some inhibition characteristics, the proteolytic activity of $B$. ruminicola $\mathrm{R} 8 / 4$ was similar to that of rumen contents.
\end{abstract}

\section{INTRODUCTION}

The proteolysis of soluble proteins in the rumen is effected primarily by cell-associated enzymes of the rumen bacterial fraction (Nugent \& Mangan, 1981; Brock \& Forsberg, 1980). The rate of degradation of different soluble proteins by rumen contents varies considerably (Mangan, 1972; Nugent \& Mangan, 1978) indicating that not only protein solubility, but also protein structure, influences rumen proteolysis.

Comparatively little is known of the nature of rumen proteinases, but a recent study showed the bacterial fraction to contain chymotrypsin- and trypsin-like enzymes, as well as other neutral proteinases and peptidases (Brock \& Forsberg, 1980). By contrast, the proteolytic rumen bacterium Bacteroides amylophilus strain $\mathrm{H} 18$ produced only a trypsin-like activity which could be almost totally inhibited by the serine proteinase inhibitor, diisopropyl fluorophosphate (Blackburn, 1968; Lesk \& Blackburn, 1971).

We describe here experiments to determine the nature of the proteolytic activity of Bacteroides ruminicola strain $\mathrm{R} 8 / 4$, a rumen bacterium which will utilize soluble proteins as a sole source of nitrogen for its growth (Hazlewood \& Nugent, 1978; Hazlewood et al., 1981).

\section{METHODS}

Growth of organism. Bacteroides ruminicola $\mathrm{R} 8 / 4$ was grown in $800 \mathrm{ml}$ batch cultures as described previously using leaf Fraction 1 protein (ribulose-1,5-bisphosphate carboxylase; EC 4.1.1.39) $\left(1 \mathrm{~g}^{-1}\right)$ as sole nitrogen source (Hazlewood et al., 1981). Bacteria in which the specific activity of proteinase was maximal were harvested during exponential growth by centrifugation $\left(12000 \mathrm{~g}, 4^{\circ} \mathrm{C}, 20 \mathrm{~min}\right)$ in capped tubes under an atmosphere of $\mathrm{O}_{2}$-free $\mathrm{N}_{2}$, and washed once with $75 \mathrm{mM}$-potassium phosphate buffer, $\mathrm{pH} 6.8$, containing $1.3 \mathrm{~mm}$-dithiothreitol. Washed cells ( $25 \mathrm{mg}$ dry wt) in $4 \mathrm{ml}$ of the same buffer were stored under $\mathrm{N}_{2}$ at $-70^{\circ} \mathrm{C}$ until required.

Bacterial growth. Culture turbidity $\left(A_{650}\right)$ was measured with an EEL colorimeter and a red filter which transmits light of wavelength exceeding $650 \mathrm{~nm}$. Standard curves were constructed relating turbidity of bacterial suspensions to dry weight.

Proteins. Unlabelled and $\left[\mathrm{U}-{ }^{14} \mathrm{C}\right]$ Fraction 1 protein were prepared as described previously (Hazlewood et al., 1981). Bovine serum albumin (BSA, crystalline), azocasein and ovalbumin (Fraction V) were from Sigma and casein from Hopkin \& Williams. 
Inhibitors. Diisopropyl fluorophosphate, iodoacetic acid, phenylmethanesulphonyl fluoride, $p$-chloromercuribenzoate, 1,10-phenanthroline and soybean trypsin inhibitor were from Sigma. Proteinase inhibitors derived from cultures of actinomycetes (antipain, chymostatin, elastatinal, leupeptin and pepstatin A; Umezawa \& Aoyagi, 1977) were obtained from the Peptide Institute (476 Ina, Minoh-shi, Osaka 562, Japan) and sterile stock solutions were prepared with regard to published solubility data.

Analytical procedures. Protein nitrogen was estimated by a micro-Kjeldahl method (Mangan \& West, 1977), the ammonia liberated from digested samples being determined by the phenol-hypochlorite reaction (Russell, 1944).

Proteinase assay. Washed $B$. ruminicola $\mathrm{R} 8 / 4$ cells (final concentration $0.45 \mathrm{mg}$ dry wt $\mathrm{ml}^{-1}$ ) suspended in 75 mM-phosphate buffer, pH 6.8 , containing $1.3 \mathrm{~mm}$-dithiothreitol at $39^{\circ} \mathrm{C}$ were added to the same buffer containing the substrate $\left(0.1 \mathrm{mg} \mathrm{ml}^{-1}\right.$ unless otherwise stated) and any additions. Dithiothreitol could be omitted from the reaction mixture if cells were preincubated for $30 \mathrm{~min}$ at $0^{\circ} \mathrm{C}$ in the presence of $1 \mathrm{~mm}$-dithiothreitol and then resuspended in $75 \mathrm{~mm}$-phosphate buffer, $\mathrm{pH} \mathrm{6.8,} \mathrm{prior} \mathrm{to} \mathrm{assay.} \mathrm{All} \mathrm{assays} \mathrm{were} \mathrm{at} 39^{\circ} \mathrm{C}$ and were terminated by rapid cooling in an ice-water bath. Depending on the substrate used, the extent of proteolysis was determined by the following procedures.

(i) $\left[\mathrm{U}-{ }^{14} \mathrm{C}\right]$ Fraction 1 protein as substrate. Bacteria were removed by centrifugation $\left(2500 \mathrm{~g}, 4^{\circ} \mathrm{C}, 10 \mathrm{~min}\right)$, and soluble radioactivity was determined before and after acid deproteinization [trichloroacetic acid (TCA) final concentration $10 \%, \mathrm{w} / \mathrm{v}$ ] as described by Hazlewood et al. (1981).

(ii) Unlabelled Fraction 1 protein, casein, BSA or ovalbumin as substrate. Bacteria were removed by centrifugation $\left(2500 \mathrm{~g}, 4^{\circ} \mathrm{C}, 10 \mathrm{~min}\right)$, and residual protein in the cell-free supernatant was sedimented by centrifugation $\left(10000 \mathrm{~g}, 4^{\circ} \mathrm{C}, 20 \mathrm{~min}\right.$ ) after the addition of TCA (final concentration $10 \%, \mathrm{w} / \mathrm{v}$ ) and determined by the Lowry method as modified by Miller (1959). A standard curve was constructed for each protein studied. The method proved highly reproducible with variation between duplicates of less than $5 \%$, but it was unsuitable for monitoring product formation when dithiothreitol was added to satisfy the requirement of the proteinase activity for a thiol reagent (Hazlewood et al., 1981) as the latter interfered with colour development $(1.3 \mu \mathrm{mol}$ dithiothreitol gave $A_{750}=1.46$ ) and no satisfactory way was found to remove or oxidize it.

(iii) Azocasein as substrate. In a modification of the method of Charney \& Tomarelli (1947), cell-free supernatant $\left(2500 \mathrm{~g}, 4{ }^{\circ} \mathrm{C}, 10 \mathrm{~min}\right)$ was deproteinized with TCA and centrifuged as described above, and a sample of the TCA-soluble fraction was mixed with an equal volume of $1 \mathrm{M}-\mathrm{NaOH} . A_{440}$ was measured and compared with a standard curve for azocasein in $0.5 \mathrm{M}-\mathrm{NaOH}$. Where required, residual protein in the TCA-pellet was redissolved in $0.5 \mathrm{M}-\mathrm{NaOH}$ and determined similarly.

All assays, and substrate and enzyme controls, were carried out in duplicate.

\section{RESULTS}

\section{Substrate specificity}

The proteolytic activity of washed, exponential phase $B$. ruminicola $\mathrm{R} 8 / 4$ cells degraded casein more rapidly than either Fraction 1 protein or BSA (Fig. 1). Both Fraction 1 protein and casein were more completely hydrolysed than BSA or ovalbumin which, under the conditions of the experiments, was degraded very slowly; after $2 \mathrm{~h}$ incubation, only about $10 \%$ of the ovalbumin had been converted to TCA-soluble products.

The rate of proteolysis of each of a number of different protein substrates at a fixed concentration of $\mathrm{R} 8 / 4$ cells $\left(0.45 \mathrm{mg}\right.$ dry $\left.w \mathrm{ml}^{-1}\right)$ depended on the initial substrate concentration. For the proteolysis of BSA, casein and Fraction 1 protein, the respective values of $K_{\mathrm{m}}$ and $V_{\max }$ were $3.18,0.43$ and $0.15 \mathrm{mg}$ protein $\mathrm{ml}^{-1}$ and $0.45,3.01$ and $0.30 \mathrm{mg}$ protein hydrolysed (mg dry wt cells) ${ }^{-1} \mathrm{~h}^{-1}$. With casein and Fraction 1 protein, substrate inhibition was apparent at concentrations above 0.4 and $0.1 \mathrm{mg} \mathrm{ml}^{-1}$, respectively. Diazotized casein was rapidly degraded by $\mathrm{R} 8 / 4$ proteinase with unchanged $K_{\mathrm{m}}$ $\left(0.45 \mathrm{mg} \mathrm{ml}^{-1}\right)$ but the value of $V_{\max }$ obtained with azocasein as substrate $1.53 \mathrm{mg}$ protein hydrolysed ( $\mathrm{mg}$ dry wt cells) $\left.{ }^{-1} \mathrm{~h}^{-1}\right]$ was considerably less than that obtained with casein. Substrate inhibition occurred when the initial azocasein concentration exceeded $0.5 \mathrm{mg} \mathrm{ml}^{-1}$.

\section{Inhibition characteristics of proteolytic activity}

Proteolysis of casein and Fraction 1 protein was inhibited $9 \%$ and $12 \%$, respectively, by $1 \mathrm{~mm}$-iodoacetic acid. $p$-Chloromercuribenzoate (at $0.1 \mathrm{mM}$ ) inhibited the activity towards 


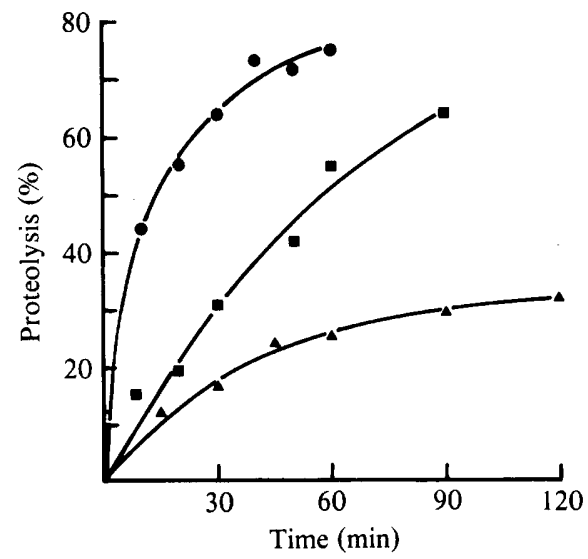

Fig. 1. Proteolysis of Fraction 1 protein $(\square)$, casein $(\mathcal{O})$ and BSA $(\boldsymbol{\Delta})$ by cell-associated proteinases of B. ruminicola $\mathrm{R} 8 / 4$. Washed exponential phase cells $\left(0.45 \mathrm{mg}\right.$ dry wt $\left.\mathrm{ml}^{-1}\right)$ suspended in $75 \mathrm{~mm}$-phosphate buffer, pH 6.8, containing $1.3 \mathrm{mM}$-dithiothreitol, were incubated at $39^{\circ} \mathrm{C}$ with each protein substrate $\left(0.1 \mathrm{mg} \mathrm{ml}^{-1}\right)$. The extent of protein degradation was determined as described in Methods.

Table 1. Effect of inhibitors on the cell-associated proteolytic activity of $B$. ruminicola $R 8 / 4$

Washed exponential phase cells $\left(0.45 \mathrm{mg}\right.$ dry $\left.\mathrm{wt} \mathrm{ml}^{-1}\right)$ suspended in $75 \mathrm{~mm}$-phosphate buffer, $\mathrm{pH} 6.8$, containing $1.3 \mathrm{~mm}$-dithiothreitol, were incubated at $39^{\circ} \mathrm{C}$ with substrate in the presence or absence of proteinase inhibitors. Proteolysis was determined as described in Methods.

\begin{tabular}{|c|c|c|c|c|}
\hline \multirow[b]{3}{*}{ Inhibitor } & \multirow{3}{*}{$\begin{array}{c}\text { Concn } \\
(\mu \mathrm{M})\end{array}$} & \multicolumn{3}{|c|}{ Percentage inhibition of proteolytic activity } \\
\hline & & \multirow{2}{*}{$\begin{array}{c}\text { Casein } \\
\text { as substrate: } \\
0.1 \mathrm{mg} \mathrm{ml}^{-1}\end{array}$} & \multicolumn{2}{|c|}{ Fraction 1 protein as substrate: } \\
\hline & & & $0.1 \mathrm{mg} \mathrm{ml}^{-1}$ & $0.05 \mathrm{mg} \mathrm{ml}^{-1}$ \\
\hline Antipain & $8 \cdot 3$ & 40 & $13-14$ & 57 \\
\hline Chymostatin & $11 \cdot 7$ & 38 & $48-60$ & 63 \\
\hline Elastatinal & $8 \cdot 5$ & 18 & $31-36$ & 53 \\
\hline Leupeptin & $11 \cdot 7$ & 42 & $20-24$ & 58 \\
\hline Pepstatin A & $7 \cdot 3$ & 32 & $28-35$ & 33 \\
\hline Soybean trypsin inhibitor & $2 \cdot 5$ & 18 & ND & 18 \\
\hline Leupeptin + EDTA (10 mM) & $11 \cdot 7$ & ND & ND & 79 \\
\hline EDTA $(10 \mathrm{~mm})$ & - & 57 & 46 & 28 \\
\hline EDTA $(20 \mathrm{~mm})$ & - & 93 & 24 & ND \\
\hline
\end{tabular}

ND, Not determined.

casein by $56 \%$ but caused precipitation of Fraction 1 protein and could not be tested with this substrate.

At $5 \mathrm{~mm}$, EDTA inhibited the rate of proteolysis of Fraction 1 protein by $75 \%$, but inhibition decreased with increasing EDTA concentration to $24 \%$ with 20 mM-EDTA. Breakdown of azocasein and casein was similarly strongly inhibited (60 to $70 \%$ ) by $10 \mathrm{~mm}$-EDTA but this inhibition increased to $90 \%$ with $20 \mathrm{~mm}$-EDTA. Another metal chelator, $1 \mathrm{mM}-1,10$-phenanthroline, inhibited by $77 \%$ the proteolysis of azocasein by cell-associated proteinases of $\mathrm{R} 8 / 4$. In the absence of inhibitors, proteolytic activity towards both Fraction 1 protein and casein was stimulated up to $30 \%$ by the addition of 10 to $20 \mathrm{mM}-\mathrm{Mg}^{2+}$ ions.

The serine proteinase inhibitors diisopropyl fluorophosphate and phenylmethanesulphonyl fluoride (each at $1 \mathrm{mM}$ ) inhibited the proteolysis of $0.5 \mathrm{mg}$ azocasein $\mathrm{ml}^{-1}$ by $26 \%$ and $21 \%$, respectively. 
The effect of naturally occurring proteinase inhibitors and EDTA on the proteolytic activity of R8/4 towards two substrates is shown in Table 1. With the exception of pepstatin $A$, the degree of inhibition produced by the microbial proteinase inhibitors depended on the nature of the protein substrate and, for a given protein, also on the initial substrate concentration. The inhibitory effect of leupeptin on hydrolysis of azocasein and Fraction 1 protein was maximal at a leupeptin concentration of $1.2 \mu \mathrm{M}$ and remained unchanged when the concentration of inhibitor was raised to $11.7 \mu \mathrm{M}$.

\section{DIS CUS SION}

In hydrolysing casein more rapidly than Fraction 1 protein or BSA the proteolytic activity of $B$. ruminicola R8/4 is similar to that of whole rumen contents (Nugent \& Mangan, 1978). Mangan (1972) suggested that the recalcitrance in the rumen of soluble proteins such as ovalbumin compared with casein or Fraction 1 protein may be a consequence of their tightly-folded globular structure. While the same would appear to be true for hydrolysis of BSA and ovalbumin by R8/4 proteinases, the proteolysis of BSA can be sufficiently rapid and complete to permit growth of the organism in a medium which contains BSA as sole nitrogen source (Hazlewood \& Nugent, 1978; Hazlewood et al., 1981).

Although casein was most rapidly degraded, $K_{\mathrm{m}}$ values indicate that the proteinases of $B$. ruminicola R8/4 have a higher affinity for Fraction 1 protein than for any of the other soluble proteins examined. This is probably because Fraction 1 protein is the major soluble protein of the leaves of green plants (Lyttleton \& T'so, 1958) and as such it is likely to be the main substrate for the proteinases of this rumen organism in vivo.

The proteolytic activity of $B$. ruminicola $\mathrm{R} 8 / 4$ was stimulated by dithiothreitol and cysteine proteinase could account for at least part (probably up to about $35 \%$ ) of the total activity (Hazlewood et al., 1981). The present work has shown that R8/4 proteinases, like those of the rumen bacterial fraction (Brock \& Forsberg, 1980), constitute a complex mixture of different activities. The use of specific inhibitors of serine proteinases (diisopropyl fluorophosphate and phenylmethanesulphonyl fluoride) and soybean trypsin inhibitor indicate that around $25 \%$ of the $\mathrm{R} 8 / 4$ proteinase activity may be serine proteinase with a possible $20 \%$ being trypsin-like. If the maximal inhibition of proteinase activity which was obtained using leupeptin, antipain, elastatinal and chymostatin with $0.05 \mathrm{mg}$ Fraction 1 protein $\mathrm{ml}^{-1}$ as substrate (Table 1) represented inhibition of both serine and cysteine proteinases, then these two types of activity could account for up to $60 \%$ of the total activity. However, inhibition of azocasein hydrolysis by iodoacetic acid indicated that only about $10 \%$ was cysteine proteinase. The proteolysis of casein and Fraction 1 protein was inhibited to the same extent (about $30 \%$ ) by pepstatin A, a powerful and specific inhibitor of aspartic acid proteinases (Barrett, 1977), indicating that roughly one-third of the bacterial activity could belong to this class.

The greater part of the proteolytic activity of $B$. ruminicola $\mathrm{R} 8 / 4$ could be inhibited by the metal chelators EDTA ( 5 to $20 \mathrm{mM}$ ) or 1,10 -phenanthroline $(1 \mathrm{mM})$, suggesting that the bulk of the activity is composed of enzymes dependent on metal ions for their function; stimulation of activity by $\mathrm{Mg}^{2+}$ ions reinforces this conclusion. However, inhibition by chelating agents is not definitive proof of the existence of a metalloenzyme since loss of activity may result from denaturation (see Knight, 1977). Further experiments would therefore be required to confirm the presence of a metalloproteinase.

On the basis of the scheme reviewed by Barrett (1977) it can tentatively be concluded that the cell-associated proteolytic activity of $B$. ruminicola R8/4 comprises a mixture of serine, cysteine and aspartic acid proteinases with the possibility that some of the activity is dependent on the presence of metal ions. 


\section{REFERENCES}

BARRETT, A. J. (1977). Introduction to the history and classification of tissue proteinases. In Proteinases in Mammalian Cells and Tissues, pp. 1-55. Edited by A. J. Barrett. Amsterdam: North-Holland Publishing $\mathrm{Co}$.

BlackbuRN, T. H. (1968). The protease liberated from Bacteroides amylophilus strain $\mathrm{H} 18$ by mechanical disintegration. Journal of General Microbiology 53, 37-51.

Brock, F. M. \& Forsberg, C. W. (1980). Proteolytic activities present in a rumen bacterial fraction. Abstracts of 30th Annual Meeting of Canadian Society of Microbiologists, F8.

Charney, J. \& Tomarelli, R. M. (1947). A colorimetric method for the determination of the proteolytic activity of duodenal juice. Journal of Biological Chemistry 171, 501-505.

Hazlewood, G. P. \& Nugent, J. H. A. (1978). Leaf Fraction 1 protein as a nitrogen source for the growth of a proteolytic rumen bacterium. Journal of General Microbiology 106, 369-371.

Hazlewood, G. P., Jones, G. A. \& Mangan, J. L. (1981). Hydrolysis of leaf Fraction 1 protein by the proteolytic rumen bacterium Bacteroides ruminicola R8/4. Journal of General Microbiology 123, 223232.

KNIGHT, C. G. (1977). Principles of the design and use of synthetic substrates and inhibitors for tissue proteinases. In Proteinases in Mammalian Cells and Tissues, pp. 583-636. Edited by A. J. Barrett. Amsterdam: North-Holland Publishing Co.

LesK, E. M. \& BlackbuRn, T. H. (1971). Purification of Bacteroides amylophilus protease. Journal of Bacteriology 106, 394-402.
Lyttleton, J. W. \& T'so, P. O. P. (1958). The localisation of Fraction 1 protein of green leaves in the chloroplasts. Archives of Biochemistry and Biophysics 73, 120-126.

MANGAN, J. L. (1972). Quantitative studies on nitrogen metabolism in the bovine rumen. The rate of proteolysis of casein and ovalbumin and the release and metabolism of free amino acids. British Journal of Nutrition 27, 261-283.

MANGAN, J. L. \& West, J. (1977). Ruminal digestion of chloroplasts and the protection of protein by glutaraldehyde treatment. Journal of Agricultural Science 89, 3-15.

Miller, G. L. (1959). Protein determination for large numbers of samples. Analytical Chemistry 31, 964.

Nugent, J. H. A. \& Mangan, J. L. (1978). Rumen proteolysis of Fraction 1 leaf protein, casein and bovine serum albumin. Proceedings of the Nutrition Society 37, 48A.

Nugent, J. H. A. \& Mangan, J. L. (1981). Characteristics of the rumen proteolysis of Fraction $1(18 \mathrm{~S})$ leaf protein from lucerne (Medicago sativa $\mathrm{L}$ ). British Journal of Nutrition (in the Press).

Russell, J. A. (1944). The colorimetric estimation of small amounts of ammonia by the phenolhypochlorite reaction. Journal of Biological Chemistry 150, 457-461.

UMEZAwA, H. \& AOYAGI, T. (1977). Activities of proteinase inhibitors of microbial origin. In Proteinases in Mammalian Cells and Tissues, pp. 637-662. Edited by A. J. Barrett. Amsterdam: North-Holland Publishing Co. 